\title{
THE A N N A S
}

AND

\section{MAGAZINE OF NATURAL HISTORY.}

\author{
[SECOND SERIES.]
}

\author{
"6................ per litora spargite muscum, \\ Naiades, et circùm vitreos considite fontes : \\ Pollice virgineo teneros hìc earpite flores : \\ Floribus et pictum, divæ, replete canistrum. \\ At vos, o Nymphæ Craterides, ite sub undas ; \\ Ite, recurvato variata corallia trunco \\ Vellite muscosis e rupibus, et mihi conchas \\ Ferte, Deæ pelagi, et pingui conchylia succo." \\ N. Parthenii Giannettasii Ecl. I.
}

Section 3. Co

ORDER. 53. I

Gen, 1. Holly (Hex)

Sp. 1. common

No. 91. JULY 1855.

I. - Observations on the Development of Gonidia (?) from the Cell-contents of the Characeæ, and on the Circulation of the Mucus-substance of the Cell; with a Postscript. By H. J. Carter, Esq., Assistant Surgeon H.C.S., Bombay.

THE following is a short summary of observations on the cellcontents of the Characeæ made in the island of Bombay during the last eight months, and which want of time only now prevents me from communicating in a more extended and complete form. All physiologists are acquainted with the development of the spiral filaments in the globule and a new plant from the nucule, but the passage of the cell-contents into gonidia in this family of the Algæ does not seem to have met with description; nor has, I think, the circulatory movement been satisfactorily explained.

Before, however, proceeding to the detail of these phænomena, it is desirable to refresh the memory of the reader with a description of the recent cell of the Characeæ in which the circulation is going on, and for this purpose I shall take an internode of Nitella, as at once furnishing the simplest and largest type of the cell throughout the family.*.

* The species of Nitella which I have used for my observations is a delicate, slender plant with long internodes and umbelliferous verticils, the Ann. \& Mag. N. Hist. Ser. 2. Vol. xvi. 
The internode of Nitella consists of-1 -1st, the cell-wall ; 2nd, the green layer; 3rd, the mucus-layer; and 4th, the axial fluid, to each of which parts separately let us now direct our attention.

Cell-wall.-This, in the internode, is cylindrical, more or less convex at each end, transparent, and resistent like all other cellulose membranes of the same kind.

Green layer.-In contact with the inner surface of the cellwall is a layer of green bodies, which, being more or less discoidal, we shall call " green disks." These disks, which are slightly separated from each other, are arranged up and down the internode in parallel lines, and the layer which they thus form is divided into two equal parts by two transparent linear intervals, which, for reasons that will appear hereafter, have been aptly termed by Slack the "lines of repose." Neither these lines, nor the lines of green disks which are parallel to them, are exactly parallel with the longitudinal axis of the internode, but twisted round it in a semispiral form, so that by transmitted light the two white intervals, which are on opposite sides of the internode, present the appearance of a cross with acute angles, which angles vary in their degree with the length of the internode.

The green disk, which is more or less elliptical and compressed, is composed of a vesicle of chlorophyll in which are three or more granules of compressed, circular or elliptical form, each of which is also, apparently, in a distinct vesicle of chlorophyll, and the whole thus grouped together form a green body which is attached to, or imbedded in, the cell-wall of a third vesicle. At least, this appears to be the typical form of the "green disk," though its component parts are not always distinctly individualized; and a vesicle with a nucleus, such as I have described, may frequently be seen among the cell-contents of the internode when the latter has been evacuated, whilst the divisions of the green disk with a granule in each, as well as faint lines between them, indicative of each being surrounded by a transparent vesicle, may often be seen while the disk is in situ. Thus, the green layer is composed of a number of vesicles set together in linear arrangement, to each of which is appended the green disk mentioned. The average size of the green disk

latter consisting of sixteen to twenty branches, alternately long and short. The long branches are thrice divided, and the last division in all terminated by a spine. The organs of fructification, which are cast together in the axils of the verticil or separately in the centres of the umbels of the branches, are, with the terminal divisions of the latter, too small to be seen distinctly by the unassisted eye. It grows here and there in the muddy tanks of the island of Bombay all the year round, and from the slime and foreign matter which collects about it, looks not unlike toad's spawn. Its chief character, when cleansed of this, is its delicate, slender, umbelliferous aspect. 
in the species of Nitella on which I have been making observations, is 1-4300th of an inch in diameter. Iodine with and without sulphuric acid gives it a dark brown-red colour, but does not turn it or its contents blue.

Mucus-layer.-Immediately within the green layer is a granular, colourless mucus, which is unequally and unevenly spread over the surface, so that it presents a wavy line towards the axial fluid. The unevenness of the inner surface of this mucus arises from partial aggregations of its substance, which are most prominent and accumulated midway between the lines of repose. One of these aggregations is generally larger than the rest, and this in the spiniform cells which terminate the branchlets and in the early state of the internode itself contains the cytoblast, which with its accompanying mucus also at this early period lines the inside of the cell; so that the whole of the granular mucus-layer and its contents, which afterwards form such a large portion of the internode, is developed from this cytoblast, and should be regarded as merely an increase in quantity of the original protoplasm or primordial utricle of Mohl.

We have now to direct our attention to the contents of the granular mucus, which, when one extremity of the internode is truncated by a sharp cutting instrument, under water, rushes out partly in a loose amorphous form, and partly enclosed in vesicles of variable dimensions, the largest of which are sometimes nearly as wide as the internode. Both the amorphous masses and vesicles are again charged with vesicles of different sizes, circular disks containing a finely granulated substance, subreniform or round starch-globules, and a number of irregularly-shaped bodies of different sizes, but of which none exceed the 1500th part of an inch in diameter.

The most striking of these contents are the circular disks, which, from their defined outline and uniform size and appearance, are easily distinguished from any of the other bodies. They average about the 2150th part of an inch in diameter, and appear to be filled with a minutely granular mucus of a very faint yellow colour, which, a certain time after the disk has been exposed to the water, contracts into an elliptical form, and thus shows that it is enclosed within a capsule, from which it is also distinct. These disks may be seen in considerable numbers loose or imbedded in the amorphous masses of mucus, or in that filling the large vesicles, or in variable plurality in transparent globular vesicles otherwise empty; lastly, they may be seen fixed singly to, or in the wall of a vesicle, which appears to be their normal appendage, and though this vesicle is sometimes hardly distinguishable, it is at others five or six times the diameter of the disk. Iodine colours the nucleus of a deep brown 
amber colour, but leaves the capsule and globular cell unaffected.

Many globular vesicles of different sizes, which appear to be entirely empty, are also to be observed, and here and there a solitary starch-globule.

But the composition of the irregular bodies, which appear to vary in size from a minute granule to the largest starch-globule, is not so evident. These bodies, which have a faint yellow opake colour, and apparently granular structure, are like the circular disks loosely scattered through the mucus, or enclosed in plurality within transparent globular vesicles otherwise empty, or attached to or imbedded singly, in the wall of one of these cells, which also seems to be their normal appendage. In Chara verticillata (Roxb.) these bodies in the early part of their growth are club-shaped, after which the large end appears to expand into an irregular, globular or agariciform head, to which the small end then forms a kind of pedicel, and thus they are also found within vesicles. At first these irregular bodies look very much like starch-granules, and particularly the agariciform ones, from the eccentric lines on their surface; but iodine, even when assisted by sulphuric acid, only turns them of a deep brown amber colour like that which it pruduces in the nucleus of the disk; sometimes it seems to have little or no effect. upon them. They differ from the circular disk in the extreme irregularity of their form, their apparent want of capsule, greater thickness, deeper yellow colour, greater opacity, and in their apparent origin from granules infinitely smaller than the circular disks.

Axial fluid.-This, as before stated, fills the centre of the internode; it is of an aqueous consistence, colourless, and frequently contains bunches of acicular raphides (oxalate of lime?), starch-globules, and many of the faint yellow irregular bodies just mentioned, all of which, except the raphides, appear to have accidentally dropt into it from the mucus-layer.

Thus we have the internode of Nitella complete, and we have only to conceive the mucus-layer moving round the axial fluid and propelling it and its particles in the same direction (by the projections on its surface), to obtain a true idea of the motion which takes place within the cell of the Characeæ.

Let us now follow the passage of the cell-contents into gonidia.

All are aware, that in the freshwater Algæ commonly called Confervæ, the formation of the spore is preceded by a breaking up or displacement of the cell-contents, after which a condensation and re-arrangement of them takes place, and they are then invested with a capsule which remains entire, until the time arrives for the spore thus formed to germinate. Now, under 
certain circumstances, which appear to be the approaching dissolution or death of the cell-wall, a similar process takes place in the cells of the Characex, and following this from the beginning, we find, that it first commences with a cessation of the circulation, after which the lines of green disks forming the green layer become displaced, and, as if obeying a still continued but inappreciable movement of the mucus-layer, they roll themselves up into lines which assume a more or less irregular arrangement across the internode, or into groups of different sizes, more or less connected by narrow lines of mucus and single disks, so as to present an areolar structure in contact with the inner surface of the cell-wall. The next stage is the separation of the disks into still more distinct groups, which, having becorne more circumscribed and circular, leave the cell-wall and evince a certain amount of polymorphism and locomotion. The cavity of the internode, hitherto rendered turbid by the breaking up of the green layer, now clears off and becomes transparent, save where the circular masses, which have changed from their original green into a brownish-green yellow colour, intercept the light. After a day or two,- but the time seems to vary, - the green disks become entirely brown, and the group, assuming a more circumscribed and circular form, shows that it is surrounded by a transparent globular cell; this we shall henceforth call the gonidial cell. A new substance, consisting of a bluish semitransparent mucus, more or less charged with minute granules (from which its colour appears to be derived), and refractive globules of a faint yellowish-green and sapphire-blue colour, makes its appearance in different parts of the brown mass, or to one side of it, and afterwards, becoming botryoidal or mulberryshaped, separates into gonidia. The brown chlorophyll with the other effete contents then shrinks up into a structureless, homogeneous, more or less defined, circular nucleus, of a dark brown colour, and the cell, frequently projecting on one side in a conical form, bursts at the apex and gives exit to the gonidia.

The gonidia are globular, ovate or spindle-shaped, and of a light blue colour. They average 1-4300th of an inch in diameter, and contain, together with the blue substance mentioned, more or less also of the refractive globules, and a transparent vesicle. Each gonidium is provided with one or two cilia according to its form, that is to say, the globular ones present one and the spindle-shaped two, which may be perceived while they are yet grouped or separate in the transparent gonidial cell, where they already exhibit a certain amount of polymorphism. Shortly after they have become free in the internode, the wall of the latter gives way and they pass into the water, where, for a certain time, they remain so active, that it is almost impossible to 
describe their form; but here and there, that which I have stated may be seen in those which are less active in their movements than the rest.

There are, however, certain peculiarities about the elongated and spindle-shaped gonidia which it is desirable to notice, viz. that one cilium appears longer than the other, and that while the short one floats almost motionless backwards, so as to appear as if it proceeded from the posterior extremity, the latter, for the most part, keeps up a constant whipping-movement in front which frequently renders it imperceptible. Both cilia however appear to be of the same length, if we add the length of the gonidium to the one which floats behind, and which is concealed in the first part of its course by lying in contact with or underneath the body of the gonidium; both also appear to be occasionally brought together anteriorly. There is also frequently a kind of proboscis extended from the rostrum or beak of the gonidium which moves incessantly, both in the ovate and spindle-shaped forms, and seems to have a suctorial extremity by means of which it fixes the gonidium to the glass, while the floating cilium also appears to be provided with a similar power and to exert it for detaching the gonidium, when so fixed, by pulling it backwards, which it does with a peculiar jerk; when this little proboscis has been present, I do not think I have ever observed the anterior or active cilium.

After a while, perhaps some hours, the gonidia become stationary, and while they appear to be fixed by the proboscis mentioned, the long cilium floats motionless, or presents a languid kind of whip-like undulation; the latter then disappears, and a day or two after, the gonidia both small and great, for there are many sizes, as will presently be mentioned, are seen creeping about the watch-glass (into which they were transferred for observation) under as active polymorphism as any amœbous cell could present; diffluent, digitated, and in the form of that beautifully radiated figure called Actinophrys Sol (Ehr.). They also now present the " contracting vesicle," as well as other vesicles, which do not appear to alter their dimensions, but vary, like the former, in distinctness with their change of position and the varying form of the gonidium. After a few days' existence in this state their polymorphism becomes very sluggish, they remain for some time under a slowly changing rhizopodous figure, which is more or less common to all, and then disappear.

Whether they germinate or not, I have not been able to determine.

Lastly, a development of transparent mucus which becomes filled with vibrios and Bacterium termo (Dujar.), immediately follows the elimination of the gonidia both in the gonidial cell 
and in the internode, presenting itself in a mass or branched organized form, more particularly at those parts of the latter which have become ruptured. This also disappears after a few days, and a thorough dissolution of the internode and its original contents seems thus to be completed.

We have now then seen that a breaking up or displacement of the green layer, a grouping of its green disks, the investment of the groups with a mucus-covering, their complete separation, their endowment with a certain amount of polymorphism and locomotion, the turning brown of the chlorophyll, and the passage of the investing mucus into a globular transparent cell, precede the evolution of the gonidial substance and its subsequent selfdivision into gonidia; let us now see if there be anything else within the gonidial cell during the time this process is going on.

It will be remembered, that a great number of discoidal bodies exist in the mucus-layer of the internode, and that many of these are loose, while others are fixed singly in the wall of a transparent vesicle; now (apparently under an arrest of development), a gonidial cell frequently presents itself, in which a single disk, with or without its vesicles, precisely similar to one of these, is seen within or to one side of the brown chlorophyll, surrounded by a shrivelled, crenulated membrane, appearing, from its irregular mulberry-like surface, want of motion, dingy colour, and absence of refractive granules, as if it were the remains of the gonidial substance which had perished from some cause or other just before it began to separate into gonidia. Moreover, in many of the disks, the nucleus is not only seen to be separated from its capsule by an annular interspace, but its granules have become larger and more distinct, and an irregular cavity like a contracted vesicle appears to exist in its centre. When the circular disk is enclosed within the brown matter, it may be rendered more evident by the addition of alcohol, which extracts the colouring matter completely, while the application of iodine deepens the colour of the brown matter, and gives a dark brown tint only to the nucleus of the disk.

That the gonidial cells should contain a nucleus within the brown matter is easily conceived, for on truncating a young internode, sometimes, in the way which I have mentioned, particularly where the green layer is soft and previously disturbed, the whole of the contents rush out together, and all the vesicles, both large and small, become surrounded with green disks, which, under these circumstances, present a similar appearance to that which is witnessed in the internode when the green layer has been broken up and its green disks separated into groups, preparatory to the development of the gonidia. 
But many of the gonidial cells are too small to contain the circular disk, and we have still to account for the disappearance of the irregular bodies of a faint yellow colour and granular structure, which appear to form a much larger proportion of the cell-contents than the circular disks.

As the smallest of the gonidial cells, which may appear in the internode, is but a very little larger than the single gonidium which it contains, and others are sometimes present which may contain fifty or more, it is obvious, that although the latter may also contain a circular disk, there is no room for it in the former. Nevertheless, the small gonidial cells containing one, two, and three gonidia, as they vary in size from the 4300 th to the 2150th of an inch in diameter, are provided with a body precisely similar to the irregular ones mentioned, which is not in the interior, but attached to or imbedded in their cell-wall, and with the latter seems to comprise all the elements of which the small gonidial cells are composed. In this way then we can account for the disappearance of the irregular bodies.

It is also not unusual to see in the older internodes, when their contents are passing into gonidial cells, a few of the green disks in situ, as well as loose in the cavity, and their disappearance also calls for explanation, which would be difficult, if we did not frequently see some of them actually in situ, under the form of gonidia, among the other green disks which have not passed into this state or departed from their original linear arrangement. Whether the gonidium has here taken the place of the green disk, or whether it has been developed in its transparent vesicle, I have not been able to determine; but in an old internode, where the basal structure of the green layer has become more or less hardened, the remains of the transparent vesicles may occasionally be seen in their original position, while the green disks have disappeared. In the fan-shaped groups of cells too, which form part of the capsule of the globule, the red granules, which are equivalent to the green disks, may frequently be seen attached, like the irregular bodies, singly or in groups, to the periphery of small gonidial cells which contain one or more gonidia. This appears to be invariably the case at the dehiscence of the globule, while the absence of circulation in these cells from the commencement would indicate a corresponding scarcity of the mucus-layer and its contents. With the exception of the central cavities of the globule and nucule, I have not seen any kind of cell in the species of Chara and Nitella, which I have had under observation, that has not produced gonidia.

Lastly, we have to account for the genuine starch-globules and raphides, both of which may be seen lying among the gonidial 
cells; but in no instance have I seen the former in the gonidial cell, or been able to produce a blue colour in the nucleus of the latter by the application of iodine.

Thus we have followed the contents of the internode of Nitella from the breaking up of the green layer to the development of the gonidia. Let us now direct our attention to the different parts of the gonidial cell analytically, more however with the object of adding to rather than recapitulating what has already been stated respecting it.

We have seen that the mucus-investment, which appears to be derived from the mucus-layer, gives the cell the power, not only of limited polymorphism, but also of locomotion; in addition to this also, the cell possesses for some time the power of projecting thread-like filaments of extreme tenuity from its surface that adhere to neighbouring objects, and thus form a point d'appui towards which the cell can then move itself. Subsequently, however, these processes, apparently following the same law of development as the cell, become stiff, and then stand out like short, straight hairs, more or less thinly scattered uver its circumference, and resembling a parasitic growth,-which some might consider them, as they do not appear on all the cells, but my impression is that they are what I have stated. I have also seen, now and then, a small gonidial cell in which the hardening process appeared not to be about to take place, but, from the rhizopodous prolongations of a part of its periphery, and its containing nothing besides the gonidial substance, presenting rather the appearance of a polymorphic spore about to germinate than to pass into a fixed cell. Occasionally the gonidial cell, after it has become stiff and transparent, presents itself under a lenticular form; at others, as if a notch had been cut in it, and sometimes with a plane surface, \&c., but all these irregularities appear to be caused by objects against which the cell rests while passing from its flexible into its hardened cellulose state. Iodine alone does not appear to impart any colour to the gonidial cell.

Immediately within the transparent globular cell is a layer of brown matter, which, as before shown, is composed of the green disks in which the chlorophyll has thus become changed in colour. This layer is also globular, and encloses the circular disk alone or with its vesicle. It often presents a botryoidal surface, which appears to be occasioned by the presence of the gonidia inside or in the midst of its substance; when the gonidia have been developed, this as well as its granular contents disappear, leaving a homogeneous, brown substance, which shrinks up into a more or less defined nucleus of a much darker colour. The brown matter is deepened in colour by the addition of iodine, and extracted by that of alcohol. In the small gonidial 
cells there appears to be no brown matter, but from the red granules, which are the equivalents of the green disks in the fanshaped group of cells forming part of the capsule of the globule, being attached singly or in groups to their periphery, it may reasonably be inferred that this is the position of the so-called brown matter in them.

After a certain time, the gonidial substance with its bright refractive granules makes its appearance in different parts of the brown matter, as if it were rising out of it, and then to one side in a distinct mass which acquires a mulberry-form and separates into gonidia; or the gonidia may be fully developed inside or in the midst of the brown matter before they make their appearance. The gonidial substance has already been described, as well as the bright refractive globules, which do not alter in colour by contact with iodine. Making its appearance then in this way, it is not extraordinary that the gonidia, in addition to their own peculiar blue-coloured mucus, which colour, as before stated, appears to depend on its granular contents, should, for the most part, also contain more or less of the refractive globules, and occasionally a fragment of the brown matter, which is the case.

I have already described the commonest form of gonidium, but there is still another about twice the size, viz. 2150th of an inch in diameter, which although not so frequent, is nevertheless sufficiently so to show, that there are two sizes more common than the rest; for we shall presently see, that the gonidial substance may occasionally come out as a whole, or in gonidia of all sizes below its original bulk. This large gonidium generally presents itself under a circular or globular form, with a single cilium, but it is sometimes seen ovate or spindle-shaped like the smaller one. It must be obvious to all, that a polymorphic cell, such as the gonidium is, can have no constant figure while in a state of activity; hence at one time it may be of one shape, and at another of another; but when under polymorphism and the cilium has disappeared, a group of gonidia will evince a strong tendency to assume the same kind of figure generally, whatever that may be. Thus, just after they become stationary, the form of Actinophrys Sol seems to prevail ; then the digitated form for progression; then the diffluent form, which appears to be produced by the more internal protoplasm bursting through that which is becoming hardened on the surface; and lastly, the tardy, rhizopodous form which I have mentioned; but I will not vouch for this sequence, and only instance it for example.

I have already alluded to the variety in size of the gonidia, but this is an exception to the general rule, for the smallest gonidial cell, in which only one gonidium is developed, yields a 
gonidium equal in size to the one first mentioned. It may how. ever yield a smaller one, and occasionally, in the same mulberry-group, may be seen gonidia of different sizes ; again, sometimes a whole group is composed of the same-sized gonidia, which are not more than half the size of the common form, that is 1-8600th of an inch in diameter; while occasionally a large mass is seen creeping about which seems equal in size to the whole of the gonidial substance of a large gonidial cell. Sometimes a compound mass of gonidia, composed of three or more which appear to have flowed into each other, may be seen, with their cilia projecting from different parts of the circumference.

I have already alluded also to the variable contents of the gonidia. In addition to the dull, bluish-green mucus, they also frequently contain more or less of the bright refractive globules, which, when the latter are beneath or in the midst of the mucus, may be mistaken for the transparent vesicles which I shall presently mention.

The gonidium may also contain more or less of the brown matter, and occasionally, when it is unusually large and of a Florence-flask shape, with the vesicle in front and a fragment of brown matter of a bright colour present, it is hardly distinguishable from Astasia.

Lastly, we come to the vesicles which are seen in the gonidium. While the gonidium retains its cilium and swimming motion, the vesicle is for the most part single, and though changeable in position with the movements of the cell-wall of the gonidium, does not appear to be endowed with contractility per se; but when it loses its cilium and sinks down to the reptant, polymorphic state, the vesicle becomes distinctly contractile, and the gonidium is then hardly distinguishable from the young Amoeba or sponge-cell. Frequently in this state also it presents one or more hyaline vesicles which are not contractile, and only change their position with those parts of the gonidium to which they may be attached.

We now come to the nucleus of the gonidial cell, and of this I can state little more than has already been given. It is evident, that although the larger ones contain a nucleus, the smaller ones do not, unless the irregular body fixed to their periphery is to be considered its equivalent. I have mentioned that the nucleus of the large cells appears to be the circular disk of the mucus-layer, and that the latter is sometimes with and sometimes without its vesicle; also that frequently, under an arrest of development, it is surrounded by a crenulated membrane. The fine granules of which the central part is composed, appear also on these occasions to have become larger and more evident, and in one instance they were replaced by three or four large glo- 
bules of a faint yellow colour, as if they had run together. In the larger gonidial cells, where a set of , healthy gonidia of normal size have been developed, the nucleus shrinks up with the effete brown matter into a common, homogeneous-looking mass, from which it is then undistinguishable.

\section{General Observations.}

Having now described the gonidial cell synthetically and analytically, let us for a few moments direct our attention to the offices of the several elements of which it is composed.

The gonidial cell, originally a portion of the mucus-layer endowed with the power of motion, at first appears to gather up a number of the green disks and wrap them round the nucleus; after which it becomes separated from the contents which it has thus enclosed, and passes into a firm, transparent membrane of a globular form, which serves to isolate and protect the materials from which the gonidia are to be developed. Lastly, it frequently assumes a conical form, which bursts at the apex and then gives exit to its gonidia. Whether the bursting is an act of its own, or induced by the distension of the mucus before mentioned, which becomes developed in it immediately after the evolution of the gonidia, and subsequently throughout the internode, I have not been able to determine; but the mucus in question is frequently seen protruding from the ruptured parts of the cell in an organized, transparent, fungoid mass, or in a branched form, as if it had caused the rupture.

This mucus appears to me worthy of notice, from its great resemblance, under the organized forms mentioned, to the gonidial substance. When within the gonidial cells and in the internode, it swarms with vibrios; but when liberated, the vibrios, after moving about for some time in the water, settle down into a form like Bacterium termo. When in the massive or branched form mentioned, bright, refractive, blue-green granules are scattered through it, and there appears to be an abortive attempt at a cellular division of the mass generally. Can this be the remnants of germinating matter which are left about the gonidial cells and the internode?

The power of the green disks, as well as the irregular bodies of the mucus-layer, to produce gonidia, is incontestable, for we have seen gonidia developed in cells where nothing else but the green disk or the irregular body was present.

What is the office then of the circular disk?

This I can only suggest from inference. It is perfectly evident that there are corpuscles in the nucule besides the starchglobules, which corpuscles resist the blue colouring action of 
iodine, and it seems equally so, that there are only these two kinds of bodies in the nucule; again, these corpuscles very closely resemble in colour, and in not becoming blue by contact with iodine, the irregular bodies contained in the mucus-layer of the internode, while they bear in other respects also a strong analogy to them. Lastly, we now know, that a gonidial cell having one of these irregular bodies for its nucleus or peripheral appendage can develope a gonidium. Thus then, if the irregular bodies and the corpuscles be identical, we have the germs of gonidial substance and starch-globules as the contents of the nucule, the latter being designed for the nourishment of the former. May not the circular disk contain nutriment for the gonidia?-while the irregular bodies would seem to be identical with the green disks, and are indeed, in many instances, almost undistinguishable from them, even when both are present among the contents of the evacuated internode.

Thus we see a great resemblance between the formation of the gonidia and the germinating of the nucule, and in the formation of both with that of the "resting spore" of Algæ generally.

As yet, $I$ have never seen a new plant developed from the gonidium of Nitella, nor have I ever been able to identify their germination with that of germinating cells, which I have frequently seen on the surface of an internode containing the gonidia; neither did Pringsheim see those germinate which came from Spirogyra, in which he has carefully described the same kind of gonidial development as that which takes place in Nitella* But Braun, who has followed the development of gonidia in Hydrodictyon $\dagger$, states, that the larger gonidia (for there are two distinct sets, which he calls macrogonidia and mierogonidia) germinate, that is, form the young water-net, while the smaller ones never do this, but unite into groups, forming a homogeneous green mass, which becomes covered with a distinct cell-membrane. This very much resembles the fungoid growth at the ruptures of and about the internode which follows the disappearance of the gonidia of Nitella, and which I have suggested might be the last efforts to form and to increase of the remnants of gonidial substance left in the gonidial cell and about the internode. Be this as it may, the dividing up of a body formed after the manner of a resting spore into smaller ones, resembling gonidia, which afterwards germinate, is the

* "On the Germination of Resting Spores and one form of Moving Spores in Spirogyra." Ann. and Mag. of Nat. Hist. vol. xi. p. 210, 1853.

+ Pub. of Ray Society, Botan. and Phys. Mem., Phænom. of Rejuvenescence in Nature. Transl. by Henfrey, p. 261. 
normal process of reproduction in Achlya prolifera*, as well as in Cladophora glomerata $\dagger$, \&c. ; and therefore it seems not impossible that, under certain circumstances, the gonidia of Nitella might produce a new plant; but this has not yet been proved; neither have we, I think, an instance on record of the resting: spore, which commonly developes a new filament, dividing upon some occasions into small spores, which can also each produce a new filament. Although Agardh $\ddagger$ saw the resting spore of Spirogyra divide up into small spores, while he was endeavouring to see the single filament developed from it which Vaucher had described, he does not state whether or not these sporules germinated. One difference between the resting spore and the gonidia is, that in the former the process of development is very slow, and in the latter very fast; hence it may be that the resting spore is only resolved into gonidia when it does not "go its full time," so to write, and therefore produces an abortive progeny; while in Achlya prolifera, where the spore does not wait until the next season for development, this is the normal process, and each small spore produces a new individual.

Since writing the above, I have been able to confirm some more observations which I had made some months since respecting another kind of passage of the cell-contents of Nitella into ciliated sacs, viz. -

About three weeks after gathering plants of Nitella and placing them in a basin of water, the green layer of the long: slender internodes becomes separated from the cell-wall, and gathered up into dark, spherical bodies, averaging about the 100th part of an inch in diameter, or large enough to be seen by the unassisted eye.

These at first move up and down the internode with the rapidity of animalcules, but afterwards lose this power of locomotion and become stationary. They then present, under the microscope, the appearance of resting spores; that is to say, they consist of a dark green, globular, grumous mass, invested with a transparent spherical cell. This green mass, in all that $I$ have examined, has been in an active state of rotation, first one way and then the other, by means of short cilia which covered its surface, like those on the spore of Vaucheria Ungeri $§$. On being crushed between two pieces of glass, this mass was found to consist chiefly of pellets of different sizes, of a deep green colour (formed of groups of green disks, respectively surrounded

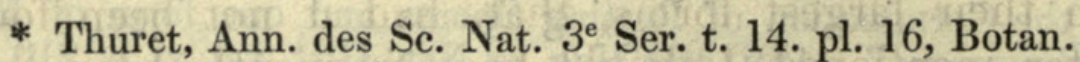

† Unger, idem, $2^{e}$ Ser. t. ii. p. 1, Botan.

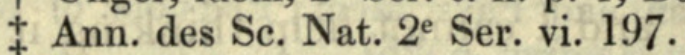

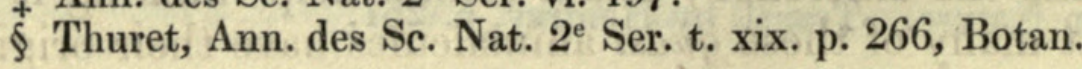


by a mucus-investment), together with a few of the commonsized gonidia, some gonidial substance, and a great number of the bright refractive globules before mentioned. Iodine gave the green pellets a deep brown colour, but did not alter in appearance the rest of the contents.

Two days after I had collected a number of these globular bodies and placed them in a watch-glass for observation, partly in and partly out of their respective internodes, the green mass in many had become divided up into four or more sacs, which were ciliated like the parent one, and enclosed in a second transparent spherical cell. These also rotated individually and en masse, while the division appeared to have enabled them to throw off the greater portion of the dark green pellets, now become blaek, and lying loosely in a more or less flocculent state, like effete matter, in the inner cell.

The third day the spherical cells had burst, and the ciliated sacs, which averaged 1-430th of an inch in diameter, were set free in the water.

They now presented different appearances, according to their contents, shape and motions. All were filled with a colourless, granular mucus, charged with small vesieles, and each presented also a large "contracting vesicle." In some there was left only a trace of the dark matter, while in others there was a considerable quantity, either in an undefined shape, or in small globules. They presented both an undulatory motion of the cell-wall, and a ciliary motion of its surface. Sometimes the cilia were motionless, and lay like a halo of short radii round its eircumference, though the sac was otherwise gradually changing its shape; while at others there was no appearance of cilia at all. On the other hand, sometimes the sac was rotating rapidly under a globular form, with its wall undulating and cilia playing over it with corresponding activity; the rotation of the sac appeared contrary to the movement of the cilia. Occasionally a sac might be seen under an elongated, oblong form, with a slowly undulatory change of shape at one end, and a languid movement of the cilia on its surface generally; again it might be seen with mucus-radii spread out in the same way as those of Actinophrys Sol.

It would, however, be endless to describe the forms which these sacs presented; but it is worthy of remark, that instead of being like those of the Amœba, they so closely resembled the order of one-celled ciliated animalcules, many of which were present in their largest forms, that, had it not been for the dark matter mentioned, I should have frequently been unable to determine the difference; and I cannot help thinking it probable, that many of these quasi animalcules have their origin in 
a similar way, and either germinate after having become stationary, or pass after a short time into dissolution, as the sacs have hitherto done which I have just described.

I had forgotten also to mention, that there is frequently a considerable space between the outer and inner spherical cell just described; and here, before the green mass has undergone division, may frequently be seen one or more of the commonsized gonidia, under their ciliated active form; which, after the division has taken place, passes into the diffluent one, when they may be seen, on the contrary, creeping slowly over the inner surface of the external spherical cell, in a polymorphic state.

The tenacity to life of the green matter and mucus-layer after the death of the cell-wall is so great in the species of Zygnema, to which I shall have occasion to allude presently, that although all the filaments broke down from the destruction and dissolution of the cell-wall a few days after they had been placed in a basin of water for examination, the mucus-layer continued to hold the spiral bands together, with but little alteration, except in form and position, for three weeks afterwards, when the whole began to break up into small parcels of green matter, of variable sizes, below the 700th part of an inch in diameter, each of which is now rounded with a mucus-investment that is carrying them about under the form of Actinophrys Sol; but with a halo of short cilia in many, immediately round the circumference, in addition to the long radii. Whether they will ultimately germinate, or their contents-now of a bright yellowish-green, but still presenting a tint of brown in it-pass into gonidia, time will show; but from the brownish tint, I should think the latter the most likely sequence.

\section{Circulation.}

What is commonly understood by the "circulation in the Characeæ," is, that the cell-contents move round the internode ; but this is a very vague idea of the phænomenon. There is but one part that moves, viz. the mucus-layer; and another part which is circulated, namely the axial fluid; while the green layer, so long as it is uninjured, remains stationary.

The axial fluid, as before stated, is impelled by the uneven surface of the mucus-layer, as may be seen by watching the motion of a bunch of the raphides when struck by one of the mucus-prominences. It will then present not only an acceleration of its progress, but, the force having been communicated to the radiated crystals next the mucus-layer, causes it to rotate backwards, or in the contrary direction to that in which it is being transported. Hence, as I have before stated that the 
aggregations are most prominent midway between the lines of repose, so the greatest impetus is given to the axial fluid and its suspended bodies in this part, while at the sides, that is, close to the lines of repose, it is remarkably slow. This was the reason why Slack* thus designated them; but he was wrong when he conceived that the dark defined surface of the mucus-layer was a membrane which was fixed to these lines throughout their course, and therefore divided the ascending from the descending current, inasmuch as the opposite currents, which are closely approximated at these parts of the internode, frequently take from each other the particles which are lingering along their direction, and thus whirl them backwards and forwards, or up and down, according to the position of the internode, until, by chance, they get into a more powerful part of the stream, and are then carried round the internode with the rest, - which would not be the case if a partition existed along the lines of repose.

Easy, however, as it is to describe the way in which the axial fluid is circulated, it is not so easy to describe the property by which the mucus-layer travels round the internode.

That Amici and Dutrochet should have ever considered the green disks instrumental in any way in effecting this in the internode of the stem, shows that neither of them recollected at this time, that the mucus-layer moves round the internode of the roots of the Characeæ in just the same manner, where there are no green disks present; while the total absence, or rare occurrence, of gonidial cells in the internodes of the roots of Characeæ, we now know to be an additional reason for inferring the absence also of the green disks there, even if they were present without their green colour to make them more visible.

That the green disk is occasionally seen to move per se, and to rotate actively in situ, has been observed by others as well as myself + ; and the observations of Donné, confirmed by Dutrochetł, prove, that under certain circumstances, viz. when in a globule of the mucus-layer, they will rotate also out of the internode; but these are exceptions to the general rule. Again, out of many scores of observations, I have seen only two instances in which the green disk (in an old internode, where most of the contents had passed into gonidial cells) presented each a cilium ; also, on one other occasion, three green disks in situ, in an internode where the circulation was going on rapidly, presented each a short thick cilium in active motion; but these,

* Trans. Soc. of Arts, vol. xlix. pt. 1, 1833.

+ Varley, Trans. Soc. of Arts, vol. xlix. pt. 2, 1833.

† Ann. des Sc. Nat. 2e Ser. t. x. 1838.

Ann.\& Mag. N. Hist. Ser. 2. Tol. xvi. 
again, may be conceived, from what I have stated, to be very rare occurrences, and, as such, are only worth remembering. The only change in the green disk which is frequently observed, is its transition from its common elliptical to a circular form, which generally accompanies a cessation of the circulation; but not always, for the former is sometimes seen when the circulation has been pernianently arrested, and the latter when it is going on with great activity.

The contraction, however, of the green layer as a whole, when the internode sustains even a slight injury, is worthy of notice. The same thing takes place in Zygnema (nitidum, mihi). On one occasion, when testing the evacuated contents of a truncated internode with tincture of iodine, I observed a fragment of the green layer, which was projecting from the orifice of the internode, to tremble rapidly when the iodine touched it; this motion, after a few seconds, became rhythmical, and then slower and slower, until it altogether ceased; thus exhibiting the same kind of convulsive motions as muscular fibre under similar circumstances. When one end of an internode is truncated with a sharp instrument, as before stated, the whole of the loose contents rush out, while the green layer remains within the internode, but retracted both from the orifice and sides of the cell-wall; and it is this contraction which appears to be the principal agency in causing the rapid expulsion of the mucuslayer, which I may here mention is every now and then drawn back into the internode spasmodically, from a contraction, apparently, of its own substance, and perhaps a momentary relaxation of the green layer at the same time. In what part of the green layer this contractile power resides, I am not able to state; but as the green disks are appended to vesicles which thus make up the green layer, and the irregular bodies of the mucus layer, which appear to be almost identical with them, have also an appended vesicle, which, a certain time after they have been exposed to the water, contracts to such an extent as to become undistinguishable from the irregular body itself, it may be the contraction of the vesicles of the green disks which produces the general contraction of the green layer.

Be this as it may, the movement which is the chief object of our consideration here is that of the mucus-layer. It has already been shown, that this is independent of the green layer; and this, combined with the power of polymorphism and locomotive agency which it presents when investing the groups of green disks preparatory to passing into the firm gonidial cell-wall, seems conclusive of its possessing an inherent power of mobility independent of any other influence, so long as it remains unaltered, and within an uninjured internode. The movement of 
rotation may appear both peculiar and unaccountable; but that of the sponge-cell, when under progression, particularly in an elongated form, is identical with it. If we watch the latter, we shall see the granules that are attached to the upper part of the cell move rapidly forwards until they arrive at the advancing boundary, where they sink down, become stationary, and remain there until the rest of the cell has passed over them, when they again ascend from behind, and again are carried on to the anterior border; and so on, as the cell progresses, after the manner of a flexible wheel. Thus the mucus-layer in the internode of Nitella rolls round an imaginary oblong axial plane, whose edges correspond with the lines of repose, where, as a matter of course, there is a long linear eddy, in which the mucus is almost stationary, as well as the axial fluid and its particles immediately beneath.

Were any further proof wanted of the independent contraction or movement of the mucus-layer, that might be cited which I have mentioned when endeavouring to account for the contractility of the green layer; but, in addition to this, I have seen the mucus-layer in an internode of the root of Chara verticillata, when the rotatory movement has been returning after having been arrested, stretch itself directly across the internode, from one part where it had become aggregated into a large mass. The jerking movements which are seen in this mucus after it has been allowed to escape from the internode in the way mentioned, seem to be owing to the successive bursting of the vesicles with which it is filled; but its diminution in bulk is indicative of something more than common contractility. Lastly, in the cells of the species of Zygnema mentioned, there is not only a ceaseless irritable contractility exhibited in the mucus-layer next the cell-wall, but also throughout the mucusthreads suspending the cytoblast; and although this motion is not rotatory, which indeed it could hardly be, with the cytoblast so suspended, yet here and there, and particularly against the septa at the extremities of the cell, aggregations of granular mucus, enclosing one or more faint yellow-coloured bodies, like that of the cytoblast, frequently present themselves, which are as unceasingly active in their polymorphism (stretching out their processes here and there) as any portions of Spongilla or $A m o b a$ that the eye meets with.

I have since seen in the youngest, or terminal cell of a filament of introverted Zygnema with single spiral band, a distinct but very irregular travelling up and down of the mucus-layer, exactly like that of the Characeæ. It can only be seen in the long delicate young cell, where the spiral band is stretched out, and where the minute granules of the mucus are congregated to 
such an extent as to indicate the presence of the moving transparent protoplasm.

Thus the phænomenon of motion in Zygnema, in Spongilla, and in the Characeæ being exhibited by the same kind of substance, in organisms so nearly allied, and in instances where there is evidently no direct connexion between it and the parent plant, leads me to view it in all as modifications of one common property, and that property a vital endowment of the same nature as contractility or power of motion generally throughout the animal kingdom.

Bombay, January 1855.

Postscript.-Since this paper was written, I have taken a different view of the nature of the so-called "gonidia" in it, viz. that they may be Infusoria, perhaps of the family Astasiaa (Ehr.), and that the "ciliated sacs" may have had a similar origin.

Contrary to what Pringsheim has stated (Ann. and Mag. Nat. Hist. vol. xi. 1853, p. 294 et seq.) respecting the integrity of the cells of Spirogyra, wherein he witnessed a similar process of development of gonidia to that which I have described above in Nitella, viz. that a supposition of such gonidia being " foreign structures, not belonging to the Spirogyra, would be an altogether inadmissible hypothesis, since they are formed in the interior of the closed filament-cells of the Spirogyræ, directly from their contents," \&c.;-contrary also to what I have myself stated above respecting the formation of the same kind of gonidia in the cells of Nitella, and where I might have also added that the cell-wall did not show any signs of decay or unsoundness until the "gonidia" were developed in the one instance, and the "ciliated sacs" in the other ; - I have nevertheless, from recent observations, been induced to doubt the correctness of this view.

While examining some filaments of Conferva in which the cells had become divided into resting spores, I perceived that one of the capsules was so far empty, that it contained nothing but a single large Astasia, which was filled with the chlorophyll and other granules of the spore, part of which had turned brown; and although the capsule of the spore was fresh and the vaginal sheath of the filament unruptured, there was a small round hole in one part passing through both that was not more than the 1-4300th of an inch in diameter, and about which the Astasia was lingering for the purpose of making its exit, but having gorged the whole of the contents of the spore, this was of course impossible.

Here then was an infusorium with a transparent flask-shaped sac terminated by a long cilium, distended by the granular contents of the spore, and so incarcerated, that it must either die 
in the spore-capsule or pass into an ovarian sac and develope its progeny much in the same manner as we have seen the "gonidial cells" in the internode of Nitella. At all events, the hole by which the Astasia entered was visible, and from its minuteness indicated a very minute size of the Astasia originally compared with that which it presented when I saw it.

Again, from Stein's valuable observations on the development of Vorticella (Ann. and Mag. Nat. Hist. vol. ix. 1852, p. 471), and latterly my own observations on this family, I can easily conceive, from the extreme minuteness with which the germs might leave the ovary of Vorticella, their rapid development under favourable circumstances, and their multiplication by fissiparation and gemmation, even when barely changed from their larval or infant, monadic form, how accidental holes may exist in the internode of Nitella, or in the cell of Spirogyra, Cladophora, or any other filamentous or thalloid Algæ, large enough to admit such germs and gemmæ, and yet pass unnoticed by the microscopist, though not by the voracious young of Infusoria.

Whenever a cell in the filamentous Algæ shows by derangement of the granular chlorophyll or gonimic contents that its functions have ceased or become interrupted, several gonidia similar to those developed in the cells of Nitella may be seen swimming about it and trying to get into it, which they do immediately the cell-wall gives way, and then fixing on its mucus-contents devour them.

All this seems to point out that the so-called gonidial development within the cells of Nitella is anything but spontaneous, while it favours the view which I have now taken, that it is infusorial.

But as we see the fragments of the contracted chlorophyllbands of Spirogyra retaining their freshness and greenness while wrapped in their mucus, for weeks after the cell-wall has passed into dissolution, a question may suggest itself, whether the contents of a resting spore when quickly swallowed by an infusorium which dies soon afterwards, might not germinate to a certain extent, under such circumstances-the sac of the infusorium supplying the place of the capsule of the spore. If so, indeed, then an infusorium would after this manner appear to develope a plant. On the other hand, if the chlorophyll turns brown, that may be considered a sign of the death of the sporecontents ; and if anything arise out of this, it must be viewed as the progeny of the infusorium, such as the so-called "gonidia" appear to be which I had described above as developed from the cell-contents of the Characeæ.

This "postscript" will not invalidate the facts in my paper, although it may affect the reasoning, from tending to change 
our view of the nature of the "gonidium" so called therein, and make it an infusorium instead of a zoospore, of which much more might be said in support if this were the place for it; and although one of the facts brought forward in proof of the independent movement of the mucus, was the polymorphism and locomotion of the gonidial cells which it was supposed to have composed, there are sufficient reasons left for my still retaining the opinion, that its contractility is not the effect of any chemical process of nutrition that is going on in the cell, though it may not be uninfluential as a physical agent in this process.

II.-Descriptions of the Animals of certain Genera of Conchifera. By S. P. Woodward, Esq., F.G.S.

MY deAR Sir,

I HEREWITH send you some more figures of the animals of certain genera of Bivalve shells (Conchifera), which Mr. Woodward has made for me, and the notes he has appended to them.

These animals have been shortly noticed by me in my paper on the Arrangement of Bivalves in the 'Annals,' vol. xiv. p. 21.

I am, my dear Sir, yours truly, J. E. Gray.

Dr. Francis.

Solen (Cultellus ?) Javanicus. Singapore.

Mantle-lobes united, covered with wrinkled epidermis ; siphons very short, fringed; no ventral orifice; pedal opening terminal. Foot straight, compressed, truncated, attached by small suspen-

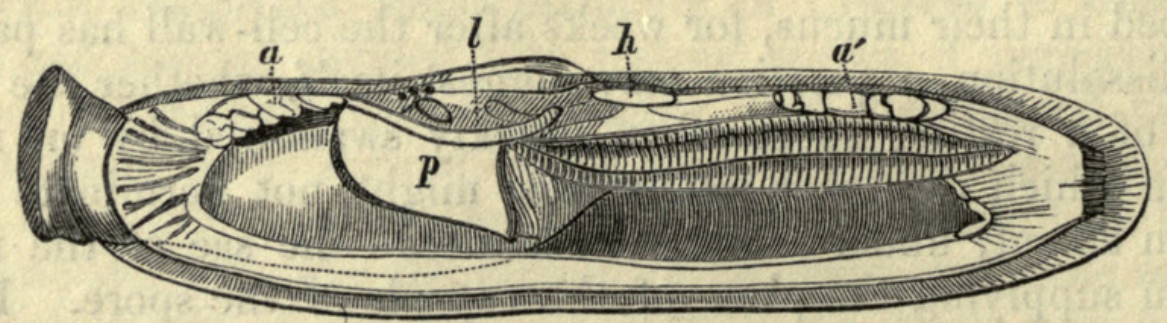

$a, a^{\prime}$, adductor muscles; $l$, liver ; $h$, heart ; $p$, palpi.

sors - two beneath the hinge, and two in front of posterior adductor. Palpi very large, oblong, pointed, attached lengthwise. Gills long, narrow, equal, plaited transversely. A long curved portion of the intestine lies close to the left side, bordering the palpi.

[This is a species of the genus Pharus.-J. E. G.] 


\section{$2 \mathrm{BHL}$ Biodiversity Heritage Library}

Carter, H. J. 1855. "I.-Observations on the development of gonidia (?) from the cell-contents of the Characeæ, and on the circulation of the mucus-substance of the cell; with a postscript." The Annals and magazine of natural history; zoology, botany, and geology 16, 1-22.

https://doi.org/10.1080/037454809495471.

View This Item Online: $\underline{\text { https://www.biodiversitylibrary.org/item/19432 }}$

DOI: https://doi.org/10.1080/037454809495471

Permalink: https://www.biodiversitylibrary.org/partpdf/30051

\section{Holding Institution}

Natural History Museum Library, London

\section{Sponsored by}

Natural History Museum Library, London

\section{Copyright \& Reuse}

Copyright Status: Public domain. The BHL considers that this work is no longer under copyright protection.

This document was created from content at the Biodiversity Heritage Library, the world's largest open access digital library for biodiversity literature and archives. Visit BHL at https://www.biodiversitylibrary.org. 